\title{
Occurrence and reproductive roles of hormones in seminal plasma
}

\author{
Jana Vitku*, Lucie Kolatorova and Richard Hampl
}

\begin{abstract}
Only $2-5 \%$ of seminal fluid is composed of spermatozoa, while the rest is seminal plasma. The seminal plasma is a rich cocktail of organic and inorganic compounds including hormones, serving as a source of nutrients for sperm development and maturation, protecting them from infection and enabling them to overcome the immunological and chemical environment of the female reproductive tract. In this review, a survey of the hormones found in human seminal plasma, with particular emphasis on reproductive hormones is provided. Their participation in fertilization is discussed including their indispensable role in ovum fertilization. The origin of individual hormones found in seminal plasma is discussed, along with differences in the concentrations in seminal plasma and blood plasma. A part of review is devoted to methods of measurement, emphasising particular instances in which they differ from measurement in blood plasma. These methods include separation techniques, overcoming the matrix effect and current ways for end-point measurement, focusing on so called hyphenated techniques as a combination of chromatographic separation and mass spectrometry. Finally, the informative value of their determination as markers of male fertility disorders (impaired spermatogenesis, abnormal sperm parameters, varicocele) is discussed, along with instances where measuring their levels in seminal plasma is preferable to measurement of levels in blood plasma.
\end{abstract}

Keywords: Hormones, Steroids, Reproductive hormones, Seminal fluid, Seminal plasma, Spermatogenesis, LC-MS, GC-MS, Immunoassay

\section{Résumé}

Les spermatozoïdes ne représentent que 2 à 25\% du liquide séminal, le reste étant constitué par le plasma séminal. Le plasma séminal est un cocktail de composés organiques et non organiques comprenant des hormones qui font office de source de substances nutritives pour le développement et la maturation des spermatozoïdes, qui les protègent de l'infection et leur permettent de surmonter l'environnement immunologique et chimique de l'appareil reproducteur féminin. La présente revue propose une vue d'ensemble des hormones retrouvées dans le plasma séminal de l'homme, l'accent étant particulièrement mis sur les hormones reproductives. La participation de ces dernières au processus de fécondation est discutée, y compris leur rôle indispensable dans la fécondation de l'ovocyte. L'origine de chacune des hormones retrouvées dans le plasma séminal est décrite, ainsi que les différences de leurs concentrations dans le plasma séminal et dans le plasma sanguin. Une partie de cette revue est dévolue aux méthodes de mesure, en soulignant des exemples particuliers où elles diffèrent des mesures dans le plasma sanguin. Ces méthodes comprennent les techniques de séparation, qui surmontent les effets matriciels et les procédures actuelles de critère de mesure, en se concentrant sur les techniques dites de couplage comme la combinaison de la séparation chromatographique et de la spectrométrie de masse. Enfin, la valeur informative de la (Continued on next page)

\footnotetext{
* Correspondence: jvitku@endo.cz

Department of Steroids and Proteofactors, Institute of Endocrinology,

Narodni 8, 11694 Prague, Czech Republic
}

(c) The Author(s). 2017 Open Access This article is distributed under the terms of the Creative Commons Attribution 4.0 International License (http://creativecommons.org/licenses/by/4.0/), which permits unrestricted use, distribution, and reproduction in any medium, provided you give appropriate credit to the original author(s) and the source, provide a link to the Creative Commons license, and indicate if changes were made. The Creative Commons Public Domain Dedication waiver (http://creativecommons.org/publicdomain/zero/1.0/) applies to the data made available in this article, unless otherwise stated. 
(Continued from previous page)

détermination de ces hormones en tant que marqueurs des anomalies de la fertilité masculine (spermatogenèse altérée, paramètres spermatiques anormaux, varicocèle) est discutée, ainsi que les situations où la mesure de leurs taux dans le plasma séminal est préférable à celle du plasma sanguin.

Mots-clés: Hormones, Stéroïdes, Hormones reproductives, Liquide séminal, Spermatogenèse, LC-MS, GC-MS, Dosage immunologique

\section{Background}

\section{The role of seminal plasma in reproduction}

Only $2-5 \%$ of the seminal fluid is composed of spermatozoa, while the rest is seminal plasma. Seminal plasma acts as a transport medium enabling the penetration of a spermatozoon into the ovum at conception. It provides several indispensable roles: First it serves as a nutritive source for the spermatozoa during their journey through the female reproductive tract. Secondly, it protects from infection and other injurious and toxic agents. Finally, due to its unique composition, it enables spermatozoa to overcome the hostile chemical and immunological milieu of the vagina. The normal vaginal environment is acidic, caused by lactic acid produced by the native microflora. Seminal plasma on the contrary contains basic amines (e.g. putrescine, spermine, spermidine and cadaverine), serving as a buffer to neutralize vaginal acidic conditions. In addition, the vaginal environment is rich in immune cells, the effect of which may be compensated for by various immuno-active molecules from the seminal plasma such as prostanoids (prostaglandins, leukotriens) [1], cytokines [2,3] and last but not least glucocorticoids [4]. Since sperm cells carry genetic information, it is very important to protect their DNA from acidic denaturation.

To fulfil all these tasks the seminal plasma contains a complex array of organic and inorganic constituents. A large portion consists of nutritive substrates, primarily fructose, citric acid, lactic acid, amino acids and other precursors of main metabolic pathways. There are more than 200 proteins, especially enzymes (such as various proteases, phosphatases etc.), as well as phospholipids, vitamins, antioxidants, and inorganic ions.

Hormones of all kinds are also found among the constituents of seminal plasma. Here we focus on steroids and other reproductive hormones, and their roles. A list of steroids found in human seminal plasma with average concentrations as measured by various authors and methods is shown in Table 1. For comparison, when available, we provide their corresponding blood levels as measured in our laboratory. The collected data from various authors until roughly 2011 were published under Reference [5]. The most striking differences in the ranges of reported physiological values may be seen in the cases of testosterone, androstenedione and especially estradiol. These discrepancies may be at least partially ascribed to different methodologies, based mainly on immunoassays or more or less advanced chromatographic techniques.

In this review the selection of the literature on hormones and in particular steroids in human seminal plasma is provided, using various combinations of key words as seminal plasma, hormone, steroid, androgens, estrogens, origin etc. Thereafter the most relevant reviews were retrieved and the principle original papers cited.

\section{The role of sex steroids in ovum fertilization}

Steroids, in concert with other components of the seminal plasma as well as from the fluid of the female reproductive tract, influence the process of penetration of the sperm into the ovum. It includes events known as capacitation of spermatozoa and the final penetration into the ovum by release of proteolytic enzymes ("acrosome reaction"). The most effective is progesterone, which is abundant in the fluid of the female reproductive tract. Through its putative membrane receptors on the human spermatozoon membrane progesterone triggers a cascade of rapid non-genomic effects such as a calcium influx, the tyrosine phosphorylation of sperm proteins, a chloride efflux and an increase of cAMP, finally resulting in activation of spermatozoa by the induction of capacitation, increased motility and the activation of proteolytic enzymes responsible for penetration of the sperm across the ovum membrane [6, 7]. However, progesterone is not the only steroid hormone modulating the acrosome reaction. Of interest may be the finding that cholesterol, the precursor of all steroid hormones, may act as an inhibitor of the progesterone effect [8].

Besides progesterone, other steroid hormones are present in both the female reproductive tract and in seminal plasma, and contribute to modulation the above processes [9]. Some in vitro studies have been undertaken to understand the effects of steroid sex hormones: human spermatozoa were incubated with testosterone [10] or estradiol [11], and the acrosome reaction was assessed by staining with Hoechst 33,258 and fluorescein isothiocyanate-conjugated $P$. sativum agglutinin lectin. While no convincing effect of testosterone was found [10], estradiol acted as an inhibitor [11]. 
Table 1 Levels of hormonal steroids and some of their precursors and metabolites in human seminal plasma and blood serum of fertile men

\begin{tabular}{|c|c|c|c|}
\hline Steroid & Seminal plasma concentration & Plasma/serum concentration & References \\
\hline Androstanediol (5a-androstane-3a17 $\beta$-diol) & $0.21-1.25$ & & [9] \\
\hline \multirow[t]{4}{*}{ Androstenedione (4-androstene-3,17-dione) } & $0.30-2.00$ & $3.0-5.0$ & See Ref. [5] \\
\hline & $1.20-2.96$ & & [9] \\
\hline & $0.056(0.035-0.087)$ & $2.036(1.857-2.228)$ & [103] \\
\hline & $3.65 \pm 1.63$ & & [128] \\
\hline \multirow[t]{2}{*}{ Cortisol } & $59-176$ & $140-690$ & See Ref. [5] \\
\hline & $13(10-15)$ & $292(267-320)$ & [103] \\
\hline Cortisone & $20.6(18.8-22.4)$ & $71.6(68.0-75.5)$ & [103] \\
\hline \multirow[t]{2}{*}{ Dehydroepiandrosterone (DHEA) } & $23.4 \pm 10.9$ & $24.3 \pm 10.3$ & [14] \\
\hline & $4.9(3.9-6.1)$ & $14.9(13.2-16.8)$ & [103] \\
\hline Dehydroepiandrosterone sulfate (DHEAS) & 1400 & $6850^{\mathrm{a}}$ & See Ref. [35] \\
\hline \multirow[t]{2}{*}{ Dihydrotestosterone } & $1.1-1.9$ & $0.87-2.6$ & See Ref. [5] \\
\hline & $0.775(0.634-0.933)$ & & [103] \\
\hline Estrone & $0.016(0.014-0.018)$ & $0.085(0.070-0.100)$ & [103] \\
\hline \multirow[t]{7}{*}{ Estradiol } & $0.2-0.6$ & below 0.18 & See Ref. [5] \\
\hline & $0.015-0.066$ & & {$[9]$} \\
\hline & $0.256 \pm 0.073$ & & {$[40]$} \\
\hline & $0.242 \pm 0.055$ & $0.086 \pm 0.023$ & [65] \\
\hline & $0.070 \pm 0.009$ & & [101] \\
\hline & $0.014(0.012-0.017)$ & $0.062(0.051-0.077)$ & [103] \\
\hline & $0.596 \pm 0.193$ & $0.095 \pm 0.04$ & [116] \\
\hline Estriol & $0.149(0.114-0.191)$ & $0.031(0.021-0.049)$ & [103] \\
\hline \multirow[t]{2}{*}{ 7a-Hydroxy-DHEA } & $1.67 \pm 0.66$ & $1.41 \pm 0.77$ & [14] \\
\hline & $0.903(0.782-1.045)$ & $0.913(0.801-1.041)$ & [103] \\
\hline \multirow[t]{2}{*}{ 7ß-Hydroxy-DHEA } & $1.45 \pm 0.67$ & $1.23 \pm 0.60$ & [14] \\
\hline & $0.210(0.174-0.246)$ & $0.489(0.437-0.545)$ & [103] \\
\hline 16a-Hydroxy-DHEA & $1.06 \pm 0.15$ & $0-1.86$ & {$[15]$} \\
\hline 17-Hydroxy pregnenolone & $0.358(0.271-0.463)$ & $4.933(4.241-5.715)$ & [103] \\
\hline 17a-Hydroxyprogesterone & $1.62 \pm 1.26$ & $1.30-5.40^{\mathrm{b}}$ & [128] \\
\hline 7-OXo-DHEA & $0.116(0.089-0.145)$ & $0.129(0.106-0.159)$ & {$[103]$} \\
\hline Pregnenolone & $0.626(0.537-0.730)$ & $1.138(0.916-1.390)$ & {$[103]$} \\
\hline Progesterone & $1.43 \pm 0.56$ & $0-3.20^{b}$ & [128] \\
\hline \multirow[t]{3}{*}{ Testosterone } & $0.3-4.6$ & $10-35$ & See Ref. [5] \\
\hline & $1.18-8.32$ & $10.0-32.2$ & {$[9]$} \\
\hline & $0.07(0.04-0.11)$ & $11.5(10.6-12.4)$ & [103] \\
\hline
\end{tabular}

The concentration ranges or means \pm S.D. or means with $95.0 \%$ confidence intervals in parenthesis in $\mathrm{nmol} / \mathrm{L}$ are shown

${ }^{\mathrm{a} S}$ Strongly dependent on age, ${ }^{\mathrm{b}}$ Data from author's laboratory

\section{Other steroids in seminal plasma}

In addition to the male and female sex steroids, many other hormonal steroids and their precursors and metabolites have been detected in seminal plasma (Table 1). Their concentrations are in most instances (but not always) lower than in blood, due to their passage through accessory sex organs or their in situ biosynthesis.
Interestingly, the ratio of biologically active hormones to their inactive counterparts (cortisol/cortisone, testosterone/ androstenedione, estradiol/estrone), reflects the activity of steroid metabolizing enzymes. These enzymes include e.g. $11 \beta$-hydroxysteroid dehydrogenase of both isotypes in semen [12] and 17ß-hydroxysteroid dehydrogenase [13] in spermatozoa. Their eventual role in maintaining an optimal 
seminal environment is not clear, but measurement of the enzyme activity in ejaculate may be useful for the diagnostics of male reproductive disorders.

With respect to the immune cells patrolling the female reproductive tract, besides prostanoids and related immunoactive molecules, the seminal plasma contains steroids with immunomodulatory properties. Both immunosuppressive cortisol and immunoprotective dehydroepiandrosterone (DHEA) and even its 7-oxygenated metabolites, believed to be the truly active DHEA metabolites, have been found in seminal plasma [14]. Another DHEA metabolite - 16 $\alpha$-hydroxy-DHEA - was hypothesized a counter regulatory steroid to 7-oxygenated steroids [15].

One of the substantive functions of the seminal fluid is also maintaining the electrolyte balance. From this point of view, the finding of an intrinsic renin-angiotensin system in the epididymis and some of it components also in testis, prostate and even in semen is of interest [16]. Information about aldosterone concentrations seems to be lacking in the literature.

Vitamin D (VD) and its active metabolite 1,25-dihydroxycholecalciferol are among the major hormones responsible for calcium homeostasis. The influx of $\mathrm{Ca}^{2+}$ participates in the acrosome reaction and calcium is present in remarkable concentrations in seminal plasma [17], the detailed mechanism was studied recently [18]. Human spermatozoa contain all the necessary machinery for its actions, including the VD receptor and VD metabolizing enzymes, the expression of which in human spermatozoa serve as positive predictive markers of sperm quality, with both genomic and non-genomic actions operating there [19-21]. Since both VD receptors and estradiol receptors are present in spermatozoa, an interaction between estrogen and VD signalling occurs there, as shown in a recent review [22]. Surprisingly, there seems to be no data on VD concentrations in seminal plasma, in contrast to numerous reports on blood serum levels [23], though it might be an interesting marker of male reproductive function.

\section{Sources of steroids in seminal plasma}

The source of most of the organic as well inorganic constituents in seminal plasma is not the testes but rather accessory sexual organs, namely seminal vesicles, the prostate, and the bulbourethral glands. During emission phase of ejaculation, part of spermatozoa from epididymis and epididymal fluid passes through the vas deferens and the ejaculatory duct - on each side- to arrive in the prostatic urethra where spermatozoa are mixed with fluid form the prostate and the seminal vesicles. In subsequent expulsion phase, spermatozoa and secretions of the previous glands are mixed with the secretions of the bulbourethral glands. Although the main source of major sex steroids are testicular Leydig cells, the male sexual organs also express the major steroidogenic enzymes as shown in Fig. 1 [24-34].

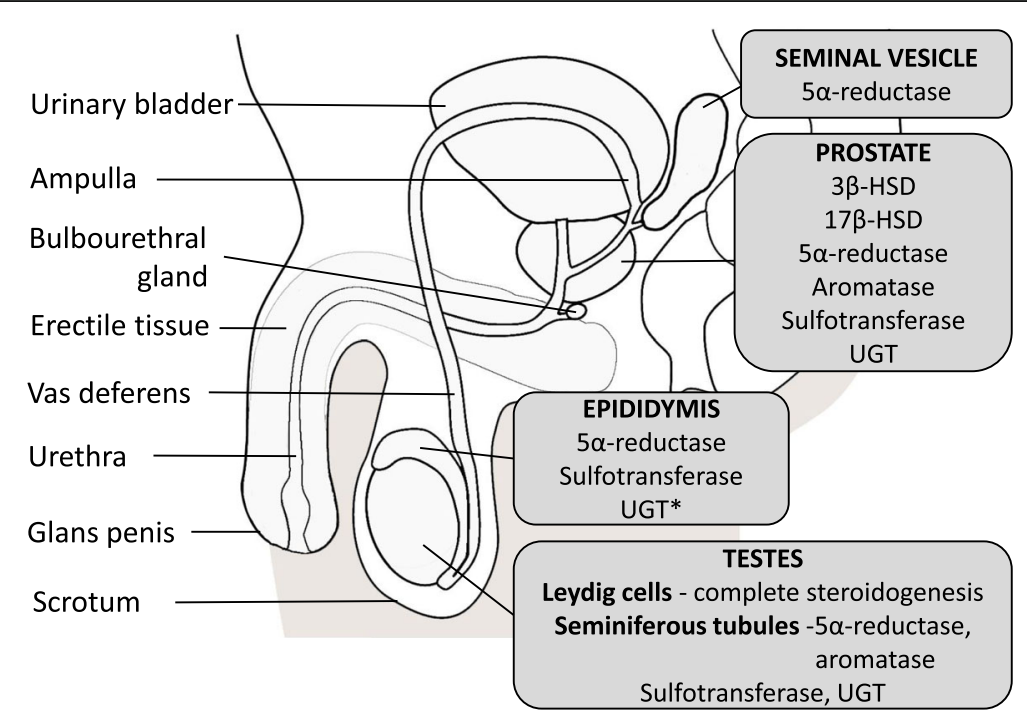

Legend: Schematic figure of male urogenital system showing the expression of major steroids in each reproductive organ - testes [24-27], prostate [28-30], seminal vesicle [31] and Epididymis [32-

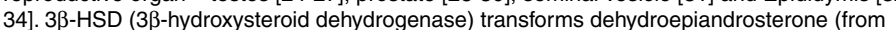

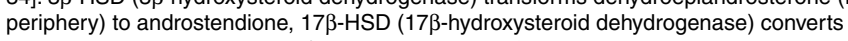
androstendione to testosterone), $5 \alpha$-reductase transforms testostosterone to dihydrotestosterone), aromatase converts testosterone to estradiol, sulfotransferase catalyses the steroid sulfatation and UDP-glucuronosyltransferase (UGT) catalyses the steroid glucuronidation.

*UGT in epididymis was reported till this time in monkeys only.

Fig. 1 Expression of major steroidogenic enzymes in human reproductive organs 
The fact that steroid concentrations in seminal plasma differ from, and in many instances do not even correlate with, their blood levels, indicates their different origin [35]. This primarily concerns the major male sex steroid, testosterone [36]. Testosterone is produced by Leydig cells and is secreted into blood and lymph. Since testosterone is necessary for spermatogenesis, it should be reabsorbed by seminiferous tubules where it must overcome hematotesticular barrier, the permeability of which differs for various steroid hormones [37, 38]. The seminiferous tubule fluid containing spermatozoa is on its route further enriched by other components from epididymis, seminal vesicles and prostate. Since the latter are also target for androgens, it may be supposed that a portion of testosterone and dihydrotestosterone measured in seminal plasma comes from these glands [39]. When compared with blood serum levels, concentrations of testosterone in seminal plasma are lower by almost by one order of magnitude, while dihydrotestosterone and progesterone concentrations are within the range similar to those in blood (Table 1).

Estradiol is the only sex steroid with concentrations in some instances higher in seminal plasma than in blood. This reflects the fact that it is synthesized in the male reproductive system by at least three cell types - Leydig and Sertoli cells and in ejaculated spermatozoa, which, in addition possess a high aromatase activity $[5,40]$.

\section{Non-reproductive hormones in seminal plasma}

Seminal plasma contains a number of protein/peptide hormones and steroids, as well as some small-molecule hormones such as catecholamines or melatonin. An alphabetical list with the hormone concentrations in seminal plasma and blood plasma/serum (if provided) is shown in Table 2.

Gonadotropins, luteinizing hormone (LH), follicle stimulating hormone (FSH) and prolactin were detected in human seminal plasma as early as the 1980s. They are believed to be transported from the blood to semen via accessory sex organs. Levels of FSH are slightly lower and on the contrary LH levels are slightly higher but within the range of those in serum [41-44]. Prolactin is mostly reported to be higher in seminal plasma [45-48].

Hypothalamic nonapeptides, oxytocin and vasopressin (an antidiuretic hormone - ADH) were found in human seminal plasma in the 1990s in amounts in the low $\mathrm{pg} / \mathrm{mL}$ range. Circulating hormones stem from the hypothalamus and are released by neurohypophysis, but there are also other peripheral sources of these hormones, especially the prostate [49-52].

Alpha and beta subunits of human chorionic gonadotropin (hCG) have been studied in human seminal plasma over the past 30 years [41, 53, 54]. The levels of beta-hCG in seminal plasma were found to be higher than in the serum and to correlate with sperm parameters [53, 54].

Antimüllerian hormone (AMH) and inhibin(s). Quite a bit of attention has been paid to seminal AMH [55-64] and to a lesser extent to inhibin B, important peptides for male as well as female reproduction $[59,61]$. The first report on AMH in seminal plasma dates from 1996 [55]. The range of physiological AMH concentrations in seminal plasma is reported to be very large - almost two orders of magnitude $[56,59,61,62,64]$. It is believed that both hormones well reflect sperm production and the development of Sertoli cells [57] and concentrations of both in seminal plasma are higher than in serum [60].

Melatonin, a small molecule produced by the pineal gland, has been also detected in seminal plasma, but its concentrations were approximately one order of magnitude lower than in blood $[44,65]$. Its presence in seminal plasma is important with respect to its antioxidant capacity as a radical scavenger $[66,67]$. Lower levels of both seminal and blood melatonin have repeatedly been found in men with impaired spermatogenesis compared to healthy fertile men $[44,68]$. Furthermore, melatonin has been suggested as a therapeutic for the improvement of sperm motility in assisted reproduction [67].

Catecholamines. There is surprisingly little information about catecholamines in seminal plasma, though they are present in considerable concentrations exceeding the levels in blood plasma. Major catecholamines - noradrenaline and adrenaline and their precursors - 3,4-dihydroxy-phenylalanine (DOPA), and 3,4-dihydroxy-phenyl acetic acid (DOPAC) were measured in seminal plasma from healthy men by HPLC as early as in 2001 [69]. Their role is still the subject of debate. It has been suggested that they participate in immunological processes enabling the penetration of sperm into the female reproductive tract, specifically participating in a local adaptive shift in the balance of $\mathrm{T}$ helper lymphocytes (Th) to a dominance of Th2 in the maternal tract $[70,71]$. However, no correlation has been found between concentrations of any of the catecholamines and semen characteristics [69].

Parathormone and calcitonin. Both of these calcium regulatory peptide hormones have been detected in human seminal plasma [72-80], to which they enter from accessory sex organs, especially the prostate [78]. From the point of view of their role in male reproduction, calcitonin is the more important, and concentrations in the semen are 30 times higher than in blood plasma [74]. No differences, however, have been found between fertile and infertile men [76], or between normo-, oligo-, or even azoospermic men [77]. The only finding has been an association of lower calcitonin content in patients with decreased sperm motility [80]. It was demonstrated, that seminal calcitonin participates in calcium regulation during the process of sperm capacitation [79]. 
Table 2 Non-steroidal hormones and their seminal plasma concentrations in fertile/normozoospermic men

\begin{tabular}{|c|c|c|c|}
\hline Hormone & Seminal plasma concentration & Plasma/serum concentration & References \\
\hline Adrenalin $(\mathrm{pg} / \mathrm{mL})$ & Not detectable - 3028 & Not detectable & [69] \\
\hline Adrenomedulin (pg/mL) & $209 \pm 19^{\mathrm{a}}$ & $23.3 \pm 2.7^{\mathrm{a}}$ & [81] \\
\hline \multirow[t]{8}{*}{ Antimullerian hormone - AMH (ng/mL) } & $1.40 \pm 0.22^{\mathrm{a}}$ & & [55] \\
\hline & $<0.49-76.02$ & $<0.49-0.38$ & [56] \\
\hline & $34.86 \pm 23.48$ & & [57] \\
\hline & $5.81 \pm 1.526$ & & [58] \\
\hline & $0.098-84.7$ & & [59] \\
\hline & $0.42-49.92$ & & [61] \\
\hline & $0.76(0.24-10.92)^{b}$ & & [62] \\
\hline & $0.34-78.18$ & $0.44-31.89$ & [64] \\
\hline \multirow[t]{5}{*}{ Calcitonin (pg/mL) } & $1771 \pm 612$ & & [73] \\
\hline & $1980 \pm 521$ & $67 \pm 13.1$ & [74] \\
\hline & $327 \pm 25$ & & [76] \\
\hline & $6846.9 \pm 3366.4$ & & [77] \\
\hline & $2367 \pm 78$ & $30 \pm 1.9$ & [80] \\
\hline \multirow[t]{2}{*}{ Follicle stimulating hormone - FSH (mIU/mL) } & $4.6 \pm 1.9$ & $9.7 \pm 6.7$ & [43] \\
\hline & $3.5 \pm 2.03$ & $5.3 \pm 2.2$ & [44] \\
\hline \multirow[t]{2}{*}{ Human chorionic gonadotropin - hCG (ng/mL) } & $1.87 \pm 0.93$ & & [53] \\
\hline & $3.73 \pm 1.60$ & & [54] \\
\hline \multirow[t]{3}{*}{ Inhibin B (pg/mL) } & $714.36 \pm 522.66$ & & [59] \\
\hline & $7.8-9874$ & $54.68 \pm 70.85$ & [61] \\
\hline & $44.0(20.7-200.3)^{b}$ & & [62] \\
\hline Luteinizing hormone - LH (mIU/mL) & $19.4 \pm 9.9$ & $13.6 \pm 8.5$ & [43] \\
\hline \multirow[t]{3}{*}{ Melatonin $(\mathrm{pg} / \mathrm{mL})$} & $44.75 \pm 11.0$ & $111.75 \pm 35.3$ & [44] \\
\hline & $1.7 \pm 1.0$ & $3.1 \pm 1.4$ & [65] \\
\hline & $23.7 \pm 10.9^{a}$ & & [68] \\
\hline Noradrenalin (pg/mL) & $15,181 \pm 2951^{a}$ & $501 \pm 136.5$ & [69] \\
\hline \multirow[t]{2}{*}{ Oxytocin (pg/mL) } & $1.72 \pm 0.78$ & & [49] \\
\hline & $61.1 \pm 11.7$ & & [51] \\
\hline Parathormone (pg/mL) & $2846 \pm 611.6$ & & [72] \\
\hline \multirow[t]{4}{*}{ Prolactin (PRL) (ng/mL) } & $3.5 \pm 0.85$ & $6.4 \pm 0.85$ & [44] \\
\hline & $46.6 \pm 2.0^{\mathrm{a}}$ & $17.8 \pm 1.7^{\mathrm{a}}$ & [46] \\
\hline & $43.2 \pm 2.7^{\mathrm{a}}$ & $6.2 \pm 0.7^{\mathrm{a}}$ & [47] \\
\hline & $133.6 \pm 47$ & $24.5 \pm 8$ & [48] \\
\hline Vasopressin (antidiuretic hormone - ADH) (pg/mL) & $1.84 \pm 1.23$ & & [52] \\
\hline
\end{tabular}

Values are expressed as means \pm standard deviations or concentration ranges. Information on blood plasma/serum concentrations is also provided if listed in the article amean \pm standard error

${ }^{\mathrm{b}}$ median (interquartile range)

Adrenomedullin. The recently discovered vasoactive peptide adrenomedullin has also been detected in seminal plasma. High levels of this hormone have been associated with decreased sperm counts, but its role in the regulation of male fertility remains unknown [81].

Thyroid hormones. Though thyroid status is important for male fertility (see e.g. Refs [82, 83]), reports on thyroid hormones in seminal plasma seem to be lacking.

\section{Methods for the determination of steroids in seminal plasma}

Since the 1970s, steroid hormones started to be measured mainly in blood, urine, and saliva, but also in seminal plasma. The main technique used became radio- and other immuno-assays, because in comparison with former analytical techniques they provided a million-fold increase in sensitivity. Later separation techniques combined with 
mass spectrometry methods were developed, and brought even greater sensitivity to steroid assessments.

Human semen coagulates immediately after ejaculation followed by liquefaction that occurs within $20 \mathrm{~min}$. Ejaculate liquefies due to proteolytic fragmentation of mainly semenogelins (Semenogelin I and II) $[84,85]$ and fibronectins [86]. Some of semen samples fail to liquefy and remain highly viscous which can indicate the disorders of accessory glands function. High viscosity can interfere with determination of some biochemical markers [87]. Whereas some of proteomic studies promptly centrifuge the sample prior liquefaction to avoid proteolysis together with adding proteases inhibitors, seminal plasma for steroid analysis is left to liquefy and subsequently undergo centrifugation to gain supernatant - seminal plasma - which is further processed or stored in $-20{ }^{\circ} \mathrm{C}$ (or $-80{ }^{\circ} \mathrm{C}$ ) until analysis.

\section{Techniques for steroid extraction and sample processing}

Many laboratories performing steroid assays employ liquid-liquid extraction (LLE) as an initial step in the purification and concentration of steroids of interest. Eventual binding to transport proteins can be completely eliminated by extraction to an organic solvent. The most common solvents used in LLE are methyl tert-butyl ether, diethyl ether, ethyl acetate, dichloromethane or mixtures of organic solvents [88]. These might be useful in reducing matrix effects, since ionized compounds, such as salts or phospholipids, do not partition into the organic layer [89]. It is important note that steroids often bind very tightly to glass. This fact has to be taken into account when developing and optimizing a method. Today, immunoassay kits often offer direct analysis without an extraction step, allowing faster analysis. Since the composition of seminal plasma and blood plasma may differ considerably, before using kits designated for blood plasma measurements they should be first validated for seminal plasma.

Chromatographic techniques usually require an extraction step as well. Apart from LLE, other possibilities for steroid sample preparation include on-line or off-line solid-phase extraction (SPE) [90] and supported liquid extraction (SLE) [91]. Compared with off-line SPE, on-line SPE is advantageous in that several steps in sample preparation are eliminated, and the automation results in better repeatability and reproducibility [92]. Technique of SLE is relatively new in steroid hormone analysis and compared to SPE, SLE included fewer steps in protocol and thus was less time consuming and potentially also cost-effective [91]. However, we know of no studies on either off-line or on-line SPE or SLE employed in assessments of seminal plasma steroids. When using gas chromatography-mass spectrometry (GC-MS), attention should be paid to any plastic material used during the sample preparation, since many plastics contain phthalates that can interfere with the final analysis.

\section{Separation techniques and hyphenated techniques}

Prior to immunoassays, paper chromatography [36], thin layer chromatography [93], column chromatography [94-97] and high performance liquid chromatography (HPLC) $[14,98]$ have been used to purify samples. These separation techniques also allow the assessment of more analytes from one sample, even if the concentrations of analysed steroids are low.

In recent years, on-line combinations of a separation technique and one or more spectroscopic detection techniques have received increasing attention, and have been termed hyphenated techniques. Liquid chromatography and gas chromatography coupled with mass detector (LC-MS and GC-MS, respectively) have become the preferred approach in steroid analysis [99]. Surprisingly, as far as we know only two groups have used hyphenated systems for determinations of steroids in seminal plasma [15, 100-103], but they assessed a broad spectrum of seminal steroids - pregnenolone, 17hydroxy-pregnenolone, cortisol, cortisone, DHEA, 16 $\alpha$ hydroxy-DHEA, $7 \alpha$-hydroxy-DHEA, $7 \beta$-hydroxy-DHEA, 7-oxo-DHEA, testosterone, androstenedione, dihydrotestosterone, estrone, estradiol and estriol.

\section{Mass spectrometry, immunoassays and their strengths and weaknesses}

Some methods for steroid determinations use an extraction and/or chromatographic step prior to end point measurements (mass spectrometry, immunoassay). However, mass spectrometry (MS) methods often allow measurement without an extraction step, and provide sufficient sensitivity despite the complex matrix. On the other hand, if the sensitivity needs to be enhanced, derivatization of steroids is a further possibility (reviewed in [104]). Estrogen phenyl groups are commonly derivatized by dansyl chloride in acetone $[100,105,106]$, on the other hand 2-hydrazino-pyridine in methanol is very effective in enhancing sensitivity of oxo as well as dioxosteroids [103, 107, 108].

It is not uncommon in immunoassays to report higher analyte concentrations in comparison with LC-MS or GC-MS systems (e.g. [109-111]). Chromatography mass spectrometry systems typically measure only a single compound (on one transition), while antibodies used in immunoassay sometimes recognize not only the target molecule but also structurally related molecules. In addition to endogenous structurally related molecules, some drugs (such as anabolic steroids and herbal medications) and natural products can cross-react with the antibody and thus increase the apparent analyte concentration [112]. 
Apart the fact that seminal sampling is noninvasive, seminal plasma is a more "suitable" matrix for immunoassays as it does not contain the common interferences present in blood plasma such as hemolysis, icterus or lipemia. Lipid levels are significantly lower in seminal plasma [113]. However, the seminal plasma proteome is as complex as the proteome of blood plasma (for review see [114]), and proteins like albumin and mucin can also interfere with the immunoassay [115].

The most noticeable difference between concentrations measured by immunoassays and MS technique is for estradiol. When a chromatographic step has been used before final measurements, estradiol levels have been reported in the low $\mathrm{pg} / \mathrm{mL}$ range (approximately to $20 \mathrm{pg} / \mathrm{mL}$ ) [9, 100-102], which is lower than in blood plasma. Immunoassays of estradiol in the seminal plasma of healthy men have given results, e.g., of $65.9 \pm 15.0 \mathrm{pg} / \mathrm{mL}$ [65], $69.7 \pm 20.0 \mathrm{pg} / \mathrm{mL}$ [40] and $162.4 \pm 52.5 \mathrm{pg} / \mathrm{mL}$ [116], which are concentrations higher than in blood plasma. This discrepancy can be explained by the cross-reactivity of antibodies with other steroids such as estrone, estriol and conjugated estrogens all of which are present in seminal plasma in higher concentrations than unconjugated estradiol [101, 102]. The results of our laboratory have shown that estrone is present in slightly higher concentration in seminal plasma as estradiol, and estriol is even 20 times higher [102]. The second reason may be the use of commercial kits that were not validated for seminal matrix. Furthermore, the limits of detections of assay kits are often higher than the estradiol levels measured by MS methods. Nevertheless, all studies have agreed that higher levels of seminal estradiol are found in men with various degree of infertility in comparison with healthy men $[9,40,102,116,117]$.

Matrix effects have been considered as the Achilles heel in LC-MS analysis [118]. To assess the matrix effects, three different strategies currently exist: (1) postcolumn infusion, (2) post-extraction addition, and (3) a comparison of the slopes of calibration curves [88]. Validation of analytical methods and evaluations of matrix effects in seminal plasma are more complicated because there is not as much seminal fluid material in comparison with e.g. blood plasma, and seminal plasma stripped of steroids is not commercially available. In blood plasma, charcoal-stripped serum is usually used for the preparation of calibration curves and quality controls. However, components of actual samples that cause matrix effects can be removed by the charcoal stripping process [88]. Modification of the sample extraction procedure and improving the chromatographic separation are essential in minimizing the matrix effects [118]. The addition of isotope-labelled internal standards at the beginning of sample preparation can be used to compensate for alterations in the signal [119].

\section{Using seminal hormones as diagnostic and prognostic tools in male fertility disorders}

The first reports on the determination of hormones in the seminal plasma appeared as early the late 1970s (for a review of the literature see Refs. [5, 35, 40]). Initially, the main focus was on how seminal hormone concentrations correlated with sperm parameters (sperm count, motility, percentage of damaged sperms etc.) and with the respective blood plasma levels. Later reports focused on more the detailed forms and causes of fertility disorders (severity of oligozoospermia, combinations with other sperm disorders such as oligoasthenozoospermia, oligoasthenoteratozoospermia and even azoospemia) $[9,40]$. Here only those hormones which may serve as markers of male fertility disorders are mentioned.

Sex steroids: The majority of studies so far have dealt with sex steroids. From the data available the following conclusions may be drawn: men with impaired spermatogenesis as given by their total sperm count, decreased motility and increased percentage of morphologically altered spermatozoa had generally lower seminal concentrations of dihydrotestosterone [36, 103] and androstenedione [9] in comparison with healthy fertile men. Their levels of estradiol $[9,40,102,103,116,117]$, other estrogenic steroids [103], DHEA [103], $5 \alpha$-androstane-3 $\alpha 17 \beta$-diol [9], progesterone [9] and 17 $\alpha$-hydroxyprogesterone [9] were increased. As for testosterone, while in most earlier reports authors did not find significant differences between healthy men and those with impaired spermatogenesis, more recent refinements of analytical methods have revealed lower seminal testosterone in oligo-, astheno- or azoospermic men (for review see $[5,40]$ ). These results have been confirmed by the recent paper of Zalata et al. [9], who also studied the effect of a varicocele in oligoasthenoteratozoospermic men, but did not find any difference between men with or without this urogenital disorder.

In conclusion, many reviews have looked for associations of serum steroid and other hormones levels with impaired spermatogenesis, but not always with definite results (see e.g. $[120,121])$. This raises the question of what advantage (if any) are determinations of seminal steroids over blood plasma analysis. Our evaluation of the available data suggests that primarily seminal dihydrotestosterone and the testosterone/estradiol ratio may be useful $[5,40]$.

Cortisol: There are only a few reports concerning seminal cortisol (see Refs $[4,103]$ ), though this steroid is known to affect negatively testosterone production in Leydig cells. An important counter-regulatory mechanism 
in these cells consists of the oxidation of excessive cortisol by $11 \beta$-hydroxysteroid dehydrogenase (11ß-HSD) type 2 . Activities of this enzyme have been measurable in semen, although seminal plasma alone was devoid of $11 \beta-H S D$ activity [12]. Cortisol along with its precursors progesterone and $17 \beta$-hydroxyprogesterone have been detected in considerable amounts in samples of sonicated specimens of sperm obtained as ejaculates from husbands of infertile couples, and their levels correlated with sperm count [122]. More studies are needed for an evaluation of cortisol and its precursors in seminal plasma as potential markers of impaired spermatogenesis.

LH, FSH and prolactin: Following their detection in seminal plasma, the levels of gonadotropins and prolactin have been compared in fertile and infertile men. Though generally lower in infertile groups, their measurement in seminal plasma did not contribute to improvements in the diagnosis of infertility in comparison with blood plasma [41, 42, 45]. On the contrary, one promising marker of male fertility disorders may be the free beta subunit of human chorionic gonadotropin [53].

Oxytocin and vasopressin: More attention has been paid to oxytocin than vasopressin due to its potential effect on sperm transport as measured by their motility. While the first report did not find any relationship between oxytocin seminal plasma levels and sperm characteristics [49], a more recent study on infertile men with varicocele revealed a significant negative correlation of seminal oxytocin with sperm count and motility, and a significant positive correlation with the percentage of abnormal sperm forms. Moreover, seminal oxytocin has been associated with varicocele grade and its bilaterality [51].

AMH and inhibin(s): In spite of their wide range of physiological concentrations, it appears that AMH and inhibin B positively correlate with parameters of sperm quality such as sperm count and motility, and negatively with the percentage of damaged spermatozoa $[56,57,64]$. $\mathrm{AMH}$ in seminal plasma was not detectable in obstructive azoospermia but it was proposed as a good marker for hypospermatogenesis in cases of non-obstructive azoospermia [56]. AMH and inhibin B have been further tested as for their predictive value for outcomes of testicular sperm extraction. It was concluded, however, that either alone or in combination they are poor predictors for this purpose $[59,61]$. On the other hand AMH and inhibin B may be successfully used for predictions of motile sperm recovery after semen cryopreservation [62]. Seminal AMH is also a good marker for assessments of recombinant FSH treatment in men with idiopathic infertility undergoing assisted reproduction cycles [63].

Seminal plasma contains a wide range of protein molecules as well. Proteomics expanded significantly over the past decade, which correlates with better analytical instrumentation and methodologies. Mass spectrometry - based proteomics is now promising tool in searching for protein biomarkers of male infertility and pathologies of male reproductive tract. Recent study of Rolland et al. determined several protein biomarkers specific to each organ of male reproductive tract that could be used in diagnostics of male infertility, especially in non-obstructive azoospermia [123]. The another study identified two protein biomarkers (ECM1 and TEX101) that can distinguish between non-obstructive and obstructive azoospermia with high sensitivity and specificity [124]. The latest analytical techniques enable measurement of post-translationally modified proteins - such glycoproteins in human seminal plasma [125] of which sialylated fibronectin was found to be associated with abnormal sperm parameters [126, 127].

\section{Conclusion}

The determination of hormones and especially reproductive hormones in seminal plasma is an important tool for the diagnostics and treatment success of male fertility disorders, and in some instances is to be preferred over determinations in blood plasma. Modern analytical approaches enable the measurement of a wide array of hormones including steroids and peptide hormones, with better sensitivity and limits of detection.

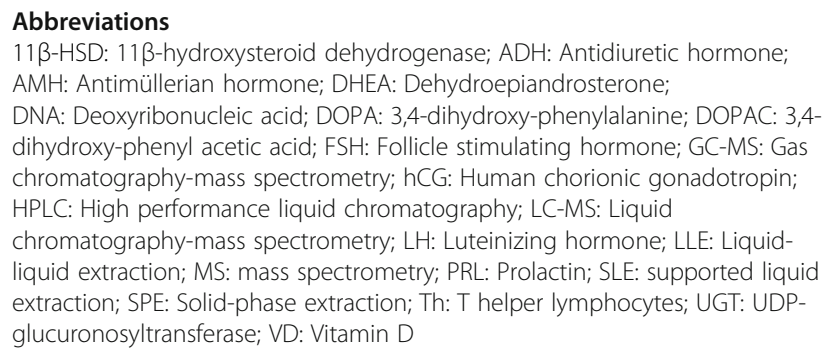

Acknowledgements

We thank David W. Hardekopf, PhD. for professional English proofreading.

\section{Funding}

This work was supported by Ministry of Health of the Czech Republic (MH CZ), grant nr. NV17-30528A, MH CZ - DRO (Institute of Endocrinology - EÚ, 00023761) and by the MEYS CR (OP RDE, Excellent research - ENDO.CZ).

\section{Availability of data and materials}

Not applicable

\section{Authors' contributions}

$\mathrm{JV}$ and $\mathrm{RH}$ wrote the manuscript. LK critically revised the manuscript.

All authors have approved the final manuscript.

Ethics approval and consent to participate

Not applicable

Consent for publication

Not applicable

Competing interests

The authors declare that they have no competing interests. 


\section{Publisher's Note}

Springer Nature remains neutral with regard to jurisdictional claims in published maps and institutional affiliations.

Received: 2 June 2017 Accepted: 16 August 2017

Published online: 13 October 2017

\section{References}

1. Saad MH, Burka JF. Isolation of leukotriene C4 from human seminal fluid. Prostaglandins. 1983;26(6):943-54.

2. Fraczek M, Kurpisz M. Cytokines in the male reproductive tract and their role in infertility disorders. J Reprod Immunol. 2015;108:98-104.

3. Gruschwitz MS, Brezinschek R, Brezinschek HP. Cytokine levels in the seminal plasma of infertile males. J Androl. 1996;17(2):158-63.

4. Brotherton J. Cortisol and transcortin in human seminal plasma and amniotic fluid as estimated by modern specific assays. Andrologia. 1990; 22(3):197-204.

5. Hampl R, Kubatova J, Sobotka V, Heracek J. Steroids in semen, their role in spermatogenesis, and the possible impact of endocrine disruptors. Horm Mol Biol Clin Investig. 2013;13(1):1-5.

6. Luconi M, Francavilla F, Porazzi I, Macerola B, Forti G, Baldi E. Human spermatozoa as a model for studying membrane receptors mediating rapid nongenomic effects of progesterone and estrogens. Steroids. 2004;69(8-9):553-9.

7. Modi DN, Shah C, Puri CP. Non-genomic membrane progesterone receptors on human spermatozoa. Soc Reprod Fertil Suppl. 2007;63:515-29.

8. Cross NL. Human seminal plasma prevents sperm from becoming acrosomally responsive to the agonist, progesterone: cholesterol is the major inhibitor. Biol Reprod. 1996;54(1):138-45.

9. Zalata A, El-Mogy M, Abdel-Khabir A, El-Bayoumy Y, El-Baz M, Mostafa T. Semina androgens, oestradiol and progesterone in oligoasthenoteratozoospermic men with varicocele. Andrologia. 2014;46(7):761-5.

10. Vigil P, Barrientos VM, Vargas GG, Machuca DA, Cortes ME. Assessment of the effect of testosterone on the acrosome reaction of human spermatozoa. Andrologia. 2012;44(Suppl 1):627-33.

11. Vigil P, Toro A, Godoy A. Physiological action of oestradiol on the acrosome reaction in human spermatozoa. Andrologia. 2008;40(3):146-51.

12. Nacharaju VL, Muneyyirci-Delale $\mathrm{O}$, Khan N. Presence of 11 betahydroxysteroid dehydrogenase in human semen: evidence of correlation with semen characteristics. Steroids. 1997:62(3):311-4.

13. Faienza MF, Giordani L, Delvecchio M, Cavallo L. Clinical, endocrine, and molecular findings in 17beta-hydroxysteroid dehydrogenase type 3 deficiency. J Endocrinol Investig. 2008;31(1):85-91.

14. Hampl R, Pohanka M, Hill M, Starka L. The content of four immunomodulatory steroids and major androgens in human semen. J Steroid Biochem Mol Biol. 2003;84(2-3):307-16.

15. Hert J, Hill M, Hampl R. Gas chromatographic-mass spectrometric identification of 16alpha-hydroxy-dehydroepiandrosterone in human seminal plasma. Steroids. 2004;69(11-12):773-7.

16. Leung PS, Sernia C. The renin-angiotensin system and male reproduction: new functions for old hormones. J Mol Endocrinol. 2003;30(3):263-70.

17. Liang H, Miao M, Chen J, Chen K, Wu B, Dai Q, et al. The association between calcium, magnesium, and ratio of calcium/magnesium in seminal plasma and sperm quality. Biol Trace Elem Res. 2016;174(1):1-7.

18. Baron L, Fara K, Zapata-Carmona H, Zuniga L, Kong M, Signorelli J, et al. Participation of protein kinases and phosphatases in the progesteroneinduced acrosome reaction and calcium influx in human spermatozoa. Andrology. 2016;4(6):1073-83.

19. de Angelis C, Galdiero M, Pivonello C, Garifalos F, Menafra D, Cariati F, et al. The role of vitamin $D$ in male fertility: a focus on the testis. Rev Endocr Metab Disord. 2017;18(3):285-305.

20. Blomberg JM. Vitamin D and male reproduction. Nat Rev Endocrinol. 2014 10(3):175-86.

21. Blomberg Jensen $M$, Dissing $S$. Non-genomic effects of vitamin D in human spermatozoa. Steroids. 2012;77(10):903-9.

22. Zanatta AP, Brouard V, Gautier C, Goncalves R, Bouraima-Lelong H, Mena Barreto Silva FR, et al. Interactions between oestrogen and 1alpha,25(OH)2 vitamin D3 signalling and their roles in spermatogenesis and spermatozoa functions. Basic Clin Androl. 2017;27:10.

23. Anagnostis $P$, Karras $S$, Goulis DG. Vitamin D in human reproduction: narrative review. Int J Clin Pract. 2013;67(3):225-35
24. MacKenzie PI, Rogers A, Elliot DJ, Chau N, Hulin JA, Miners JO, et al. The novel UDP glycosyltransferase 3A2: cloning, catalytic properties, and tissue distribution. Mol Pharmacol. 2011;79(3):472-8.

25. Song WC, Qian Y, Sun X, Negishi M. Cellular localization and regulation of expression of testicular estrogen sulfotransferase. Endocrinology. 1997; 138(11):5006-12

26. Thackare $\mathrm{H}$, Nicholson HD, Whittington K. Oxytocin-its role in male reproduction and new potential therapeutic uses. Hum Reprod Update. 2006;12(4):437-48.

27. Schulster M, Bernie AM, Ramasamy R. The role of estradiol in male reproductive function. Asian J Androl. 2016;18(3):435-40.

28. Pelletier $\mathrm{G}$. Expression of steroidogenic enzymes and sex-steroid receptors in human prostate. Best Pract Res Clin Endocrinol Metab. 2008;22(2):223-8.

29. Qin X, Liu M, Wang X. New insights into the androgen biotransformation in prostate cancer: a regulatory network among androgen, androgen receptors and UGTs. Pharmacol Res. 2016:106:114-22.

30. Takase Y, Luu-The V, Poisson-Pare D, Labrie F, Pelletier G. Expression of sulfotransferase $1 \mathrm{E} 1$ in human prostate as studied by in situ hybridization and immunocytochemistry. Prostate. 2007;67(4):405-9.

31. Imperato-McGinley J, Zhu YS. Androgens and male physiology the syndrome of 5alpha-reductase-2 deficiency. Mol Cell Endocrinol. 2002;198(1-2):51-9.

32. Roberts KD. Sterol sulfates in the epididymis; synthesis and possible function in the reproductive process. J Steroid Biochem. 1987;27(1-3):337-41.

33. Barbier $\mathrm{O}$, Belanger A, Hum DW. Cloning and characterization of a simian UDP-glucuronosyltransferase enzyme UGT2B20, a novel C19 steroidconjugating protein. Biochem J. 1999;337(Pt 3):567-74.

34. Robaire B, Hamzeh M. Androgen action in the epididymis. J Androl. 2011; 32(6):592-9.

35. Hampl R, Kubatova J, Heracek J, Sobotka V, Starka L. Hormones and endocrine disruptors in human seminal plasma. Endocr Regul. 2013;47(3):149-58,

36. Zalata A, Hafez T, Verdonck L, Vermeulen L, Comhaire F. Androgens in seminal plasma: markers of the surface epithelium of the male reproductive tract. Int J Androl. 1995:18(5):271-7.

37. Mruk DD, Cheng CY. The mammalian blood-testis barrier: its biology and regulation. Endocr Rev. 2015;36(5):564-91.

38. Cheng CY, Mruk DD. The blood-testis barrier and its implications for male contraception. Pharmacol Rev. 2012;64(1):16-64.

39. Wilson JD. The critical role of androgens in prostate development Endocrinol Metab Clin N Am. 2011:40(3):577-90. ix

40. Zhang Q, Bai Q, Yuan Y, Liu P, Qiao J. Assessment of seminal estradiol and testosterone levels as predictors of human spermatogenesis. J Androl. 2010; 31(2):215-20.

41. Asch RH, Fernandez EO, Siler-Khodr TM, Pauerstein CJ. Peptide and steroid hormone concentrations in human seminal plasma. Int J Fertil. 1984;29(1):25-32.

42. Garcia Diez LC, Gonzalez Buitrago JM, Corrales JJ, Battaner E, Miralles JM. Hormone levels in serum and seminal plasma of men with different types of azoospermia. J Reprod Fertil. 1983;67(1):209-14.

43. Abbaticchio G, Giorgino R. FSH and LH in human semen: a diagnostic trial for male infertility. Arch Androl. 1983;10(1):85-9.

44. Awad H, Halawa F, Mostafa T, Atta H. Melatonin hormone profile in infertile males. Int J Androl. 2006;29(3):409-13.

45. Smith ML, Luqman WA. Prolactin in seminal fluid. Arch Androl. 1982:9(2):105-13.

46. Segal S, Ron M, Laufer N, Ben-David M. Prolactin in seminal plasma of infertile men. Arch Androl. 1978:1(1):49-52.

47. Merino G, Canales ES, Vadillo ML, Forsbach G, Solis J, Zarate A. Abnormal prolactin levels in serum and seminal plasma in infertile men. Arch Androl. 1980;4(4):353-5.

48. Koskimies Al, Hovatta O, Ranta T, Seppala M. Serum and seminal plasma prolactin levels in oligospermia. Int J Fertil. 1978;23(1):76-8.

49. Goverde HJ, Bisseling JG, Wetzels AM, Braat DD, Pesman GJ, Sweep FC, et al. A neuropeptide in human semen: oxytocin. Arch Androl. 1998;41(1):17-22.

50. Isola M, Cossu M. A DEL, Isola R, Massa D, Casti a, et al. oxytocin immunoreactivity in the human urethral (Littre's) glands. J Reprod Dev. 2010;56(1):94-7.

51. Mostafa T, Rashed LA, Osman I, Marawan M. Seminal plasma oxytocin and oxidative stress levels in infertile men with varicocele. Andrologia. 2015: 47(2):209-13.

52. Brotherton J. Vasopressin: another pregnancy protein in human seminal plasma. Andrologia. 1990;22(4):305-7.

53. Caroppo E, Niederberger C, lacovazzi PA, Correale M, Palagiano A, D'Amato G. Human chorionic gonadotropin free beta-subunit in the human seminal plasma: a new marker for spermatogenesis? Eur J Obstet Gynecol Reprod Biol. 2003;106(2):165-9. 
54. Saito S, Kumamoto Y, Ito N, Kurohata T. Human chorionic gonadotropin beta-subunit in human semen. Arch Androl. 1988;20(1):87-99.

55. Fallat ME, Siow Y, Belker AM, Boyd JK, Yoffe S, MacLaughlin DT. The presence of mullerian inhibiting substance in human seminal plasma. Hum Reprod. 1996;11(10):2165-9.

56. Fenichel P, Rey R, Poggioli S, Donzeau M, Chevallier D, Pointis G. AntiMullerian hormone as a seminal marker for spermatogenesis in nonobstructive azoospermia. Hum Reprod. 1999;14(8):2020-4.

57. Fujisawa M, Yamasaki T, Okada H, Kamidono S. The significance of antiMullerian hormone concentration in seminal plasma for spermatogenesis. Hum Reprod. 2002;17(4):968-70.

58. Mostafa T, Amer MK, Abdel-Malak G, Nsser TA, Zohdy W, Ashour S, et al. Seminal plasma anti-Mullerian hormone level correlates with semen parameters but does not predict success of testicular sperm extraction (TESE). Asian J Androl. 2007:9(2):265-70.

59. Duvilla E, Lejeune H, Trombert-Paviot B, Gentil-Perret A, Tostain J, Levy R. Significance of inhibin B and anti-Mullerian hormone in seminal plasma: a preliminary study. Fertil Steril. 2008;89(2):444-8.

60. Sinisi AA, Esposito D, Maione L, Quinto MC, Visconti D, De Bellis A, et al. Seminal anti-Mullerian hormone level is a marker of spermatogenic response during long-term gonadotropin therapy in male hypogonadotropic hypogonadism. Hum Reprod. 2008;23(5):1029-34.

61. Mitchell V, Boitrelle F, Pigny P, Robin G, Marchetti C, Marcelli F, et al. Seminal plasma levels of anti-Mullerian hormone and inhibin $B$ are not predictive of testicular sperm retrieval in nonobstructive azoospermia: a study of 139 men. Fertil Steril. 2010;94(6):2147-50.

62. Nery SF, Vieira MA, Dela Cruz C, Lobach VN, Del Puerto HL, Torres PB, et al. Seminal plasma concentrations of anti-Mullerian hormone and inhibin B predict motile sperm recovery from cryopreserved semen in asthenozoospermic men: a prospective cohort study. Andrology. 2014;2(6):918-23.

63. Caprio F, De Franciscis P, Trotta C, lanniello R, Mele D, Colacurci N. Seminal anti-Mullerian hormone levels during recombinant human folliclestimulating hormone treatment in men with idiopathic infertility undergoing assisted reproduction cycles. Andrology. 2015;3(5):843-7.

64. Kucera R, Ulcova-Gallova Z, Windrichova J, Losan P, Topolcan O. AntiMullerian hormone in serum and seminal plasma in comparison with other male fertility parameters. Syst Biol Reprod Med. 2016;62(3):223-6.

65. Luboshitzky R, Shen-Orr Z, Herer P. Seminal plasma melatonin and gonadal steroids concentrations in normal men. Arch Androl. 2002;48(3):225-32.

66. du Plessis SS, Hagenaar K, Lampiao F. The in vitro effects of melatonin on human sperm function and its scavenging activities on NO and ROS. Andrologia. 2010:42(2):112-6.

67. Ortiz A, Espino J, Bejarano I, Lozano GM, Monllor F, Garcia JF, et al. High endogenous melatonin concentrations enhance sperm quality and short-term in vitro exposure to melatonin improves aspects of sperm motility. J Pineal Res. 2011;50(2):132-9.

68. Kratz EM, Piwowar A, Zeman M, Stebelova K, Thalhammer T. Decreased melatonin levels and increased levels of advanced oxidation protein products in the seminal plasma are related to male infertility. Reprod Ferti Dev. 2016;28(4):507-15

69. Fait G, Vered Y, Yogev L, Gamzu R, Lessing JB, Paz G, et al. High levels of catecholamines in human semen: a preliminary study. Andrologia. 2001; 33(6):347-50.

70. Yun AJ, Daniel SM. Sympathetic and T helper (Th)2 bias may ameliorate uterine fibroids, independent of sex steroids. Med Hypotheses. 2005;65(6):1172-5.

71. Bazar KA, Yun AJ, Lee PY. Immunomodulatory function of seminal catecholamines may be an adaptation for reproduction. Med Hypotheses. 2004;63(1):168-71.

72. Brotherton J. Parathyroid hormone: another pregnancy protein present in human seminal plasma and amniotic fluid. Andrologia. 1991;23(1):57-9.

73. Sjoberg HE, Arver S, Bucht E. High concentration of immunoreactive calcitonin of prostatic origin in human semen. Acta Physiol Scand. 1980; 110(1):101-2.

74. Foresta C, Caretto A, Indino M, Betterle C, Scandellari C. Calcitonin in human seminal plasma and its localization on human spermatozoa. Andrologia. 1986;18(5):470-3.

75. Singer R, Bruchis S, Sagiv M, Allalouf D, Levinsky H, Kaufman H. Betaendorphin and calcitonin in human semen. Arch Androl. 1989;23(1):77-81.

76. Davidson A, Vermesh M, Paulson RJ, Graczykowski JW, Lobo RA. Presence of immunoreactive beta-endorphin and calcitonin in human seminal plasma, and their relation to sperm physiology. Fertil Steril. 1989;51(5):878-80.
77. Badr O, Imam A, Monieb H, Khalifa A, Al Ahmady O, Abdallah MA. Concentration of calcitonin in seminal plasma of infertile men. Andrologia. 1989;21(5):416-22.

78. Shah GV, Noble MJ, Austenfeld M, Weigel J, Deftos L, Mebust WK. Presence of calcitonin-like immunoreactivity (iCT) in human prostate gland: evidence for iCT secretion by cultured prostate cells. Prostate. 1992;21(2):87-97.

79. Fraser LR, Adeoya-Osiguwa SA, Baxendale RW, Gibbons R. Regulation of mammalian sperm capacitation by endogenous molecules. Front Biosci. 2006;11:1636-45.

80. Mungan NA, Mungan G, Basar MM, Baykam M, Atan A. Effect of seminal plasma calcitonin levels on sperm mobility. Arch Androl. 2001;47(2):113-7.

81. Marinoni E, Vellucci O, Letizia C, Sessa M, Moscarini M, Di lorio R. The level of adrenomedullin immunoreactivity in seminal fluid is higher in oligozoospermic subjects and correlates with semen biochemical parameters. Eur J Obstet Gynecol Reprod Biol. 2007:131(2):169-75.

82. Krassas GE, Pontikides $\mathrm{N}$. Male reproductive function in relation with thyroid alterations. Best Pract Res Clin Endocrinol Metab. 2004;18(2):183-95.

83. Rajender S, Monica MG, Walter L, Agarwal A. Thyroid, spermatogenesis, and male infertility. Front Biosci (Elite Ed). 2011;3:843-55.

84. Robert M, Gagnon C. Semenogelin I: a coagulum forming, multifunctional seminal vesicle protein. Cell Mol Life Sci. 1999:55(6-7):944-60.

85. Lundwall A, Bjartell A, Olsson AY, Malm J. Semenogelin I and II, the predominant human seminal plasma proteins, are also expressed in nongenital tissues. Mol Hum Reprod. 2002;8(9):805-10.

86. Lilja H, Oldbring J, Rannevik G, Laurell CB. Seminal vesicle-secreted proteins and their reactions during gelation and liquefaction of human semen. J Clin Invest. 1987;80(2):281-5.

87. World Health Organisation. WHO laboratory manual for the examination and processing of human semen. Fifth edition. 2010.

88. Wang Q, Mesaros C, Blair IA. Ultra-high sensitivity analysis of estrogens for special populations in serum and plasma by liquid chromatography-mass spectrometry: assay considerations and suggested practices. J Steroid Biochem Mol Biol. 2016;162:70-9.

89. Novakova L. Challenges in the development of bioanalytical liquid chromatography-mass spectrometry method with emphasis on fast analysis. J Chromatogr A. 2013;1292:25-37.

90. Makin HLJ, Honour JW, Shackleton CH Griffiths WJ. General Methods for the Extraction, Purification, and Measurement of Steroids by Chromatography and Mass Spectrometry, in Steroid Analysis, H.L.J. Makin and D.B. Gower, Editors. Springer.2010:163-282.

91. Owen LJ, Keevil BG. Supported liquid extraction as an alternative to solid phase extraction for LC-MS/MS aldosterone analysis? Ann Clin Biochem. 2013;50(Pt 5):489-91.

92. Naldi AC, Fayad PB, Prevost M, Sauve S. Analysis of steroid hormones and their conjugated forms in water and urine by on-line solid-phase extraction coupled to liquid chromatography tandem mass spectrometry. Chem Cent J. 2016;10:30.

93. Kurniawan E, Tamm J, Volkwein U, Schirren C. Unconjugated 5 alphaandrostan-3 alpha, 17 beta-diol and 5 alpha-androstane-3 beta, 17 beta-diol in normal and pathological human seminal plasma. Comparison with testosterone, 5 alpha-dihydrotestosterone and testosterone-glucosiduronate. Andrologia. 1983;15(2):141-50.

94. Laudat A, Guechot J, Palluel AM. Seminal androgen concentrations and residual sperm cytoplasm. Clin Chim Acta. 1998;276(1):11-8.

95. Adamopoulos DA, Lawrence DM, Swyer Gl. Determinantion of testosterone concentration in semen of men with normal or subnormal sperm counts and after vasectomy. Acta Eur Fertil. 1976;7(3):219-25.

96. Facchinetti F, Comitini G, Genazzani A, Bakalakis C, Genazzani AR, Loche S. Seminal fluid androgen levels in infertile patients. Int J Fertil. 1987;32(2):157-61.

97. Santiemma V, Rosati P, Fazzi V, Bolelli GF, Guerzoni C, Fabbrini A. Seminal estrone, estrone sulfate, and estradiol-17 beta levels in fertile and infertile males. Arch Androl. 1991:26(2):129-34.

98. Schwartz JI, Tanaka WK, Wang DZ, Ebel DL, Geissler LA, Dallob A, et al. MK386, an inhibitor of 5alpha-reductase type 1, reduces dihydrotestosterone concentrations in serum and sebum without affecting dihydrotestosterone concentrations in semen. J Clin Endocrinol Metab. 1997;82(5):1373-7.

99. Wilson ID, Brinkman UA. Hyphenation and hypernation the practice and prospects of multiple hyphenation. J Chromatogr A. 2003;1000(1-2):325-56.

100. Vitku J, Chlupacova T, Sosvorova L, Hampl R, Hill M, Heracek J, et al. Development and validation of LC-MS/MS method for quantification of bisphenol $a$ and estrogens in human plasma and seminal fluid. Talanta 2015;140(0):62-67 
101. Reiffsteck A, Dehennin L, Scholler R. Estrogens in seminal plasma of human and animal species: identification and quantitative estimation by gas chromatography-mass spectrometry associated with stable isotope dilution. J Steroid Biochem. 1982:17(5):567-72.

102. Vitku J, Sosvorova L, Chlupacova T, Hampl R, Hill M, Sobotka V, et al. Differences in bisphenol $\mathrm{a}$ and estrogen levels in the plasma and seminal plasma of men with different degrees of infertility. Physiol Res. 2015 64(Suppl. 2):S303-11.

103. Vitku J, Heracek J, Sosvorova L, Hampl R, Chlupacova T, Hill M, et al. Associations of bisphenol A and polychlorinated biphenyls with spermatogenesis and steroidogenesis in two biological fluids from men attending an infertility clinic. Environ Int. 2016;89-90:166-73.

104. Higashi T, Ogawa S. Chemical derivatization for enhancing sensitivity during LC/ESI-MS/MS quantification of steroids in biological samples: a review. J Steroid Biochem Mol Biol. 2016;162:57-69.

105. Wang HX, Wang B, Zhou Y, Jiang QW. Rapid and sensitive analysis of phthalate metabolites, bisphenol a, and endogenous steroid hormones in human urine by mixed-mode solid-phase extraction, dansylation, and ultraperformance liquid chromatography coupled with triple quadrupole mass spectrometry. Anal Bioanal Chem. 2013;405(12):4313-9.

106. Zhao Y, Boyd JM, Sawyer MB, Li XF. Liquid chromatography tandem mass spectrometry determination of free and conjugated estrogens in breast cancer patients before and after exemestane treatment. Anal Chim Acta. 2014;806:172-9.

107. Higashi T, Nishio T, Hayashi N, Shimada K. Alternative procedure for charged derivatization to enhance detection responses of steroids in electrospray ionization-MS. Chem Pharm Bull (Tokyo). 2007;55(4):662-5.

108. Sosvorova L, Vitku J, Chlupacova T, Mohapl M, Hampl R. Determination of seven selected neuro- and immunomodulatory steroids in human cerebrospinal fluid and plasma using LC-MS/MS. Steroids. 2015;98:1-8.

109. Chang YC, Li CM, Li LA, Jong SB, Liao PC, Chang LW. Quantitative measurement of male steroid hormones using automated on-line solid phase extraction-liquid chromatography-tandem mass spectrometry and comparison with radioimmunoassay. Analyst. 2003;128(4):363-8.

110. French $D$. Advances in bioanalytical techniques to measure steroid hormones in serum. Bioanalysis. 2016;8(11):1203-19.

111. Duskova M, Sosvorova L, Vitku J, Jandikova H, Racz B, Chlupacova T, et al. Changes in the concentrations of corticoid metabolites-the effect of stress, diet and analytical method. Prague Med Rep. 2015;116(4):268-78.

112. Krasowski MD, Drees D, Morris CS, Maakestad J, Blau JL, Ekins S. Crossreactivity of steroid hormone immunoassays: clinical significance and twodimensional molecular similarity prediction. BMC Clin Pathol. 2014;14:33.

113. Lu JC, Jing J, Yao Q, Fan K, Wang GH, Feng RX, et al. Relationship between lipids levels of serum and seminal plasma and semen parameters in 631 Chinese subfertile men. PLoS One. 2016;11(1):e0146304

114. Drabovich AP, Saraon P, Jarvi K, Diamandis EP. Seminal plasma as a diagnostic fluid for male reproductive system disorders. Nat Rev Urol. 2014;11(5):278-88

115. Chen JT, Hortin GL. Interferences with semen detection by an immunoassay for a seminal vesicle-specific antigen. J Forensic Sci. 2000;45(1):234-5.

116. Bujan L, Mieusset R, Audran F, Lumbroso S, Sultan C. Increased oestradiol level in seminal plasma in infertile men. Hum Reprod. 1993;8(1):74-7.

117. Luboshitzky R, Kaplan-Zverling M, Shen-Orr Z, Nave R, Herer P. Seminal plasma androgen/oestrogen balance in infertile men. Int J Androl. 2002; 25(6):345-51.

118. Taylor PJ. Matrix effects: the Achilles heel of quantitative high-performance liquid chromatography-electrospray-tandem mass spectrometry. Clin Biochem. 2005;38(4):328-34.

119. Stokvis E, Rosing H, Beijnen JH. Stable isotopically labeled internal standards in quantitative bioanalysis using liquid chromatography/mass spectrometry: necessity or not? Rapid Commun Mass Spectrom. 2005;19(3):401-7.

120. Bourcigaux N, Christin-Maitre S. Hormonal evaluation in infertile men. Gynecol Obstet Fertil. 2008;36(5):551-6.

121. Sussman EM, Chudnovsky A, Niederberger CS. Hormonal evaluation of the infertile male: has it evolved? Urol Clin North Am. 2008;35(2):147-55. vii

122. Chew PC, Loganath A, Peh KL, Chow WP, Gunasegaram R, Ratnam SS. Concentrations of intracellular sex steroids in human spermatozoa. Arch Androl. 1993;30(3):165-70.

123. Rolland AD, Lavigne R, Dauly C, Calvel P, Kervarrec C, Freour T, et al. Identification of genital tract markers in the human seminal plasma using an integrative genomics approach. Hum Reprod. 2013;28(1):199-209.
124. Drabovich AP, Dimitromanolakis A, Saraon P, Soosaipillai A, Batruch I, Mullen B, et al. Differential diagnosis of azoospermia with proteomic biomarkers ECM1 and TEX101 quantified in seminal plasma. Sci Transl Med. 2013;5(212):212ra160.

125. Saraswat M, Joenvaara S, Tomar AK, Singh S, Yadav S, Renkonen R. NGlycoproteomics of human seminal plasma glycoproteins. J Proteome Res. 2016;15(3):991-1001.

126. Katnik-Prastowska I, Kratz EM, Faundez R, Chelmonska-Soyta A. Lower expression of the alpha2,3-sialylated fibronectin glycoform and appearance of the asialo-fibronectin glycoform are associated with high concentrations of fibronectin in human seminal plasma with abnormal semen parameters. Clin Chem Lab Med. 2006:44(9):1119-25.

127. Kratz EM, Faundez R, Katnik-Prastowska I. Fucose and sialic acid expressions in human seminal fibronectin and alpha\{1\}-acid glycoprotein associated with leukocytospermia of infertile men. Dis Markers. 2011;31(5):317-25.

128. Feuring M, Bertsch $T$, Tran BM, Rossol-Haseroth $K$, Losel R, Tillmann HC, et al. Seminal plasma hormone concentration after oral application of progesterone. Int J Clin Pharmacol Ther. 2002;40(2):47-52.

\section{Submit your next manuscript to BioMed Central and we will help you at every step:}

- We accept pre-submission inquiries

- Our selector tool helps you to find the most relevant journal

- We provide round the clock customer support

- Convenient online submission

- Thorough peer review

- Inclusion in PubMed and all major indexing services

- Maximum visibility for your research

Submit your manuscript at www.biomedcentral.com/submit
Biomed Central 